\title{
Analisis Faktor-Faktor yang Mempengaruhi Keterikatan Karyawan pada Hotel Berbintang di Batam
}

\author{
YUSWARDI, SE., MM \\ Universitas Internasional Batam \\ yuswardi003@gmail.com
}

\begin{abstract}
Abstrak Penelitian ini bertujuan untuk mengetahui pengaruh dari variabel kepemimpinan, kepuasan kerja, lingkungan kerja, kompensasi dan pelatihan kerja terhadap keterikatan karyawan hotel berbintang yang ada di Batam. Penelitian ini perlu dilakukan untuk mendapatkan informasi mengenai faktor-faktor yang berpengaruh terhadap peningkatan keterikatan kerja karyawan hotel berbintang di Batam.

Penelitian ini dilakukan dengan metode survei melalui penyebaran kuesioner kepada 350 responden yang merupakan karyawan lima hotel berbintang yangmemiliki jumlah karyawan terbanyak di Batam. Setelah kuesioner disebarkan dan dikumpulkan kembali oleh penulis, berhasil didapatkan 350 kuesioner yang diisi dengan lengkap sehingga bisa dilakukan pengujian data regresi oleh penulis dengan menggunakan program SPSS. Dari hasil pengolahan data dengan SPSS diketahui bahwa terdapat hubungan pada hampir semua variabel yang diteliti.

Hasil penelitian ini menekankan tentang pentingnya bagi manajemen hotel berbintang untuk memberikan perhatian yang lebih besar pada variabel yang diteliti diatas. Karena hampir semua variabel tersebut diatas mempunyai hubungan erat dengan keterikatan karyawan, sehingga bila perusahaan ingin meningkatkan keterikatan karyawannya maka hal tersebut diatas harus ditingkatkan dan diperbaiki.
\end{abstract}

Kata Kunci kepemimpinan, kepuasan kerja, lingkungan kerja, kompensasi dan pelatihan kerja, keterikatan karyawan dan hotel berbintang

\section{PENDAHULUAN}

Employee engagement atau keterikatan karyawan terhadap perusahaan menjadi topik penting yang paling dibicarakan dalam beberapa tahun terakhir di antara perusahaan konsultan dan media bisnis terkenal (Ologbo \& Sofian, 2013). Employee engagement merupakan gagasan yang penting dalam perilaku organisasi yang banyak ditulis oleh para praktisi dan perusahaan konsultasi. Employee engagement memang sudah menjadi perhatian dari para praktisi dalam manajemen sumber daya manusia. Dalam literatur akademis, dikatakan bahwa engagement berhubungan dengan gagasan lain dalam perilaku organisasi (Ologbo \& Sofian, 2013). Gagasan dalam perilaku organisasi ini sama-sama berbicara tentang hubungan karyawan dengan perusahaan. Sebagai salah satu gagasan dalam perilaku organisasi, employee engagement berbeda dengan gagasan lain 
seperti komitmen organisasi. Komitmen organisasi merupakan sikap dan keterkaitan terhadap organisasi. Sementara employee engagement bukan merupakan sikap, melainkan tingkat dimana seorang individu penuh perhatian dan senang dalam melakukan tugas yang diberikan oleh perusahaan.

Menurut Azeem et al., (2015), tingkat engagement di perusahaan kelas dunia lebih baik dibandingkan dengan perusahaan lain. Pada perusahaan kelas dunia (world-class) karyawan yang tergolong ke dalam golongan engaged mencapai tingkat $67 \%$ sedangkan perusahaan lain hanya mencapai $33 \%$. Tingkat engagement pada perusahaan kelas dunia juga lebih kecil daripada perusahaan lain. Karyawan pada perusahaan kelas dunia yang termasuk ke dalam not engaged dan actively disengaged berturut-turut hanya sebesar $26 \%$ dan $7 \%$, bandingkan dengan perusahaan lain yang mencapai $49 \%$ dan $18 \%$. Artinya bahwa masih banyak perusahan yang belum memberi perhatian lebih pada employee engagement meskipun employee engagement sangat memberikan manfaat bagi perusahaan.

Sebagai salah satu pintu masuk wisatawan ke Indonesia dan juga wisatawan domestik untuk bepergian ke luar negeri, kegiatan pariwisata di Batam cukup berkembang. Hal ini ditunjukkan dengan banyaknya jasa akomodasi perhotelan di Batam. Dengan semakin meningkatnya kegiatan pariwisata di Batam, maka jumlah hotel berbintang dan non bintang juga turut meningkat di Batam. Saat ini jumlah hotel di Batam mencapai 130 unit yang terdiri dari 53 hotel berbintang 1 sampai 4, dan 70 hotel non bintang dengan total kamar mencapai 6.500 unit dan tingkat hunian rata-rata di atas 60 persen (www.bpsbatam.co.id).

Karyawan yang puas dan termotivasi akan peduli, merasa memiliki, atau mengabdikan diri terhadap bisnis organisasi secara maksimal dan bekerja secara tim untuk meningkatkanperformance bagi organisasi. Menurut Ali dan Farooqi (2014) bahwa keterikatan karyawan (employee engagement) terhadap perusahaan menjelaskan seberapa besar seseorang merasa bersemangat dan merasa senang (excitement) dalam bekerja. Karyawan yang merasa terikat adalah yang merasa benar-benar terlibat dan memiliki antusias akan pekerjaan dan organisasinya. Keterikatan adalah kemauan dan kemampuan untuk berkontribusi terhadap keberhasilan perusahaan, yakni pada kondisi karyawan mau berupaya keras menuntaskan pekerjaannya, kalau perlu dengan waktu yang ekstra dengan menggunakan segenap pikiran dan energinya.

Keterikatan karyawan atau sering disebut employee engagement adalah sebuah pernyataan psikologis dimana karyawan merasa tertarik untuk ikut menentukan kesuksesan perusahaan serta memiliki keinginan dan motivasi kuat untuk berkinerja melebihi kewajibannya. Ali dan Farooqi (2014) mendefinisikan employee engagement sebagai suatu sikap positif dari karyawan terhadap organisasi tempat karyawan bekerja. Employee engagement dapat mempengaruhi kualitas kerja karyawan dan meningkatkan kepuasan kerja, mengurangi jumlah ketidakhadiran karyawan dan menurunkan kecenderungan untuk berpindah pekerjaan. Keterikatan emosi yang tinggi mempengaruhi karyawan dalam menyelesaikan pekerjaan dan cenderung memiliki kualitas kerja yang memuaskan dan akan berdampak pada rendahnya keinginan karyawan untuk meninggalkan perusahaan.

Gaya kepemimpinan adalah suatu cara yang digunakan oleh seorang pemimpin dalam mempengaruhi perilaku orang lain. Gaya kepemimpinan merupakan norma perilaku yang dipergunakan oleh seseorang pada saat orang tersebut mencoba mempengaruhi perilaku orang lain. Masing-masing gaya tersebut memiliki keunggulan 
dan kelemahan. Seorang pemimpin akan menggunakan gaya kepemimpinan sesuai kemampuan dan kepribadiannya (Aghashahi et al., 2013). Emhan (2012) menyatakan bahwa kepuasan kerja juga dipengaruhi oleh fungsi dan kedudukan karyawan dalam organisasi, dimana karyawan yang berkedudukan lebih tinggi merasa lebih puas karena mereka mempunyai otonomi yang lebih besar dan akan mempunyai keterikatan kerja yang lebih baik terhadap organisasi.

Lingkungan kerja merupakan kondisi yang ada di tempat kerja baik itu fisik maupun non fisik yang turut mempengaruhi pegawai dalam menjalankan pekerjaannya dan suasana yang dirasakan oleh pegawai di dalam organisasinya yang berkaitan dengan sikap dan tindakan rekan maupun pimpinan serta iklim kerja akan mempengaruhi keterikatan karyawan pada perusahaan.

\section{LANDASAN TEORI \\ Keterikatan Karyawan}

Naidoo dan Martins (2014) mendefenisikan keterikatan karyawan atau sering disebut employee engagement adalah sebuah pernyataan psikologis dimana karyawan merasa tertarik untuk ikut menentukan kesuksesan perusahaan serta memiliki keinginan dan motivasi kuat untuk berkinerja melebihi kewajibannya. Ali dan Farooqi (2014) mendefinisikan employee engagement sebagai suatu sikap positif dari karyawan terhadap organisasi tempat dirinya bekerja. Employee engagement muncul sebagai upaya pengembangan dari konsep-konsep sebelumnya seperti kepuasan kerja karyawan, komitmen karyawan, serta perilaku organisasi karyawan. Dengan adanya karyawan yang terlibat secara aktif di dalam perusahaan menandakan bahwa perusahaan tersebut memiliki iklim kerja yang positif. Hal ini disebabkan karena dengan adanya karyawan yang memiliki keterikatan yang baik dengan perusahaan tempat ia bekerja, maka mereka akan memiliki antusiasme yang besar untuk bekerja, bahkan terkadang jauh melampaui tugas pokok yang tertuang dalam kontrak kerja karyawan.

Ologbo dan Sofian (2013) dalam penelitiannya meneliti tentang pengaruh dari variabel kepemimpinan, citra perusahaan dan penghargaan \& kompensasi terhadap keterikatan karyawan pada pegawai swasta yang bekerja di beberapa perusahaan di Malaysia. Keterikatan karyawan (employee engagement) terhadap perusahaan menjelaskan seberapa besar seseorang merasa bersemangat (passion) dan merasa senang (excitement) dalam bekerja. Penelitian yang dilakukan oleh Naidoo dan Martins (2014) ini bertujuan untuk meneliti hubungan antara budaya kerja perusahaan dengan keterikatan karyawan pada perusahaan ritel di bidang sistem informasi di Afrika Selatan. Penelitian ini diharapkan dapat memberikan masukan pada perusahaan tersebut dalam meningkatkan tingkat keterikatan karyawan.

Penelitian selanjutnya dilakukan oleh Swathi (2013) pada beberapa institusi bidang pendidikan di India. Dalam penelitiannya peneliti menginvestigasi hubungan dan pengaruh dari kepemimpinan di lingkungan universitas terhadap tingkat keterikatan karyawan dari tenaga pengajar, staf administrasi, kepala departemen dan juga staff non pengajar. Penelitian berikutnya dilakukan oleh Ali dan Farooqi (2014) yang bertujuan untuk mengidentifikasi pengaruh dari kelebihan beban kerja karyawan terhadap tingkat kepuasan kerja dan pengaruh kepuasan kerja terhadap keterlibatan karyawan. Penelitian ini dilakukan dengan cara menyebarkan kuesioner kepada karyawan Universitas Gujranwala di Pakistan termasuk dosen pengajar dan staf non pengajar. Penelitian ini penting dilakuakan dilingkungan universitas karena beban kerja yang termasuk tinggi 
pada kalangan akademisi dan dosen di Pakistan perlu diteliti pengaruhnya terhadap tingkat keterlibatan kerja.

Penelitian Suharti dan Suliyanto (2012), yang meneliti hubungan antara budaya lingkungan kerja dan gaya kepeminpinan sebagai variabel independen dan keterikatan karyawan sebagai variabel dependen. Penelitian ini dilakukan pada 102 responden yang karyawan perhotelan di Indonesia. Penelitian berikutnya oleh Lai et al., (2015) yang meneliti hubungan antara pelatihan kerja dan dukungan dari rekan kerja sebagai variabel independen dan keterikatan karyawan sebagai variabel dependen. Penelitian ini dilakukan pada responden yang bekerja di hotel berbintang di Kuala Lumpur, Malaysia. Dengan tingkat persaingan yang cukup tinggi pada bidang imdustri perhotelan di Malaysia membuat tingkat keterikatan kerja karyawan hotel perlu ditingkatkan.

\section{Hubungan Antar Variabel}

\section{Pengaruh Kepemimpinan terhadap Keterikatan Karyawan}

Kepemimpinan adalah kemampuan untuk mempengaruhi orang lain untuk mencapai tujuan dengan antusias (Swathi, 2013). Kepemimpinan adalah konsep yang lebih sempit daripada manajemen. Manajer dalam organisasi formal bertanggung jawab dan dipercaya dalam melaksanakan fungsi manajemen. Pemimpin yang terdapat pada kelompok informal, tidak selalu bertanggung jawab atas fungsi-fungsi manajemen. Seorang manajer yang ingin berhasil maka dituntut untuk memiliki kepemimpinan yang efektif.

Perhatian yang ditunjukkan pemimpinan terhadap karyawan dapat memicu rasa aman kepada karyawan, sehingga sabagai gantinya karyawan akan membayar kembali dan menunjukkan loyalitas kepada organisasi dan keterikatan yang kuat pada organisasi. Pemimpin yang bersedia mendengarkan dan mempertimbangkan pendapat bawahan, berpartisipasi dan selalu memberikan dukungan akan membuat bawahan merasa dihormati sehingga dapat menciptakan keterikatan karyawan (Surharti \& Suliyanto, 2012). Kepercayaan dan dukungan dari pemimpin dapat dianggap sebagai keamanan secara psikologi sehingga dapat mengarah keterlibatan karyawan. Pemimpin yang selalu berkomunikasi dan mendukung bawahannya dan selalu memberikan motivasi terhadap pekerjaan bawahan, sehingga menciptakan pemikirian yang selaras anatara bawahan dan atasan akan mempengaruhi cara berkerja karyawan untuk organisasi dan kepuasan dalam kerja (Azeem et al., 2015).

\section{Pengaruh Lingkungan Kerja terhadap Keterikatan Karyawan}

Lingkungan kerja didefinisikan sebagai segala sesuatu yang berada disekitar karyawan yang mempengaruhi karyawan dalam menjalankan dan menyelesaikan tugastugas yang diberikan kepadanya dalam suatu wilayah kerja karyawan (Anita, 2014). Lingkungan kerja yang sehat secara emosional dan fisik dapat memotivasi karyawan menjadi terikat. Lingkungan kerja yang sehat dan memiliki tantangan pekerjaan akan membuat merasa bekerja dalam berkompetisi antar karyawan sehingga termotivasi dan tertantang dalam melakukan setiap pekerjaan yang diberikan. Suasana pekerjaan yang penuh dengan kompetisi baik, akan meningkatkan ataupun menyebabkan keterikatan karyawan pada perusahaan (Naidoo \& Martins, 2014).

Dimensi dan penataan perabotan, penataan ruangan, tingkat kebisingan, suhu ruangan, jumlah dan aksesibilitas file dan tempat penyimpanan dan tinggi partisi tempat kerja memiliki dampak yang besar terhadap kepuasan kerja dan kinerja, baik individu dan 
tim. Sebuah lingkungan kerja yang efektif yang positif dan mendukung memungkinkan karyawan untuk bekerja dengan nyaman dan memiliki kemauan untuk memberikan komitmen penuh dan kontribusi dalam melakukan tugas yang diberikan. Kenyamanan lingkungan merupakan hal yang dibutuhkan oleh karyawan untuk melakukan pekerjaan dan kegiatan dengan baik. Penelitian sebelumnya dari Anita (2014), Naidoo dan Martins (2014) menemukan bahwa terdapat hubungan yang signifikan antara lingkungan kerja dengan keterikatan karyawan.

\section{Pengaruh Kompensasi terhadap Keterikatan Karyawan}

Kompensasi didefinisikan sebagai pemberian upah atau imbalan kepada pegawai atau sesuatu yang diterima pegawai sebagai balas jasa atas prestasinya kepada perusahaan dalam melaksanakan pekerjaan (Ravikumar, 2013). Kompensasi dalam bentuk ekonomi diberikan dalam bentuk gaji, upah, tunjangan, bonus, insentif dan lain-lain. Sistem kompensasi membantu dalam memberi penguatan terhadap nilai-nilai kunci organisasi serta memfasilitasi pencapaian tujuan organisasi. Menurut Sundaray (2012) kompensasi memiliki pengaruh yang sangat besar pada hubungan kinerja karyawan. Kompensasi tidak selalu berupa gaji dan tunjangan, namun juga keperdulian perusahaan terhadap karyawan dan sebagainya. Organisasi harus memiliki sistem manajemen kompensasi yang tepat sehingga karyawan bermotivasi untuk bekerja di organisasi. Kompensasi yang diberikan berupa pengakuan ataupun apresiasi atas pekerjaan yang dilakukan dan kompensasi seperti gaji, bonus akan membuat karyawan menjadi lebih profesional sehingga akan menyebabkan keterikatan karyawan pada perusahaan (Ologbo \& Sofian, 2013).

\section{Pengaruh Kepuasan Kerja terhadap Keterikatan Karyawan}

Vokić dan Hernaus (2015) mendefinisikan kepuasan kerja sebagai hasil dari penilaian dari pekerja dan sejauh mana lingkungan kerja memenuhi kebutuhan pekerja. Kepuasan kerja mengacu pada sikap dan perasaan pekerja tentang kondisi pekerjaan mereka. Sundaray (2014) mengemukakan bahwa kepuasan kerja adalah perasaan atau tanggapan afektif terhadap suasana kerja. Kepuasan kerja adalah sikap umum terhadap pekerjaan seseorang, yang menunjukkan perbedaan antara jumlah penghargaan yang diterima pekerja dan jumlah yang mereka yakini seharusnya diterima oleh karyawan. Ali dan Farooqi, (2014) mendefinisikan kepuasan kerja sebagai hasil dari penilaian dari pekerja dan sejauh mana lingkungan kerja memenuhi kebutuhan pekerja. Kepuasan kerja mengacu pada sikap dan perasaan pekerja tentang kondisi pekerjaan mereka. Sikap positif terhadap pekerjaan menunjukkan kepuasan kerja sedangkan sikap negatif terhadap pekerjaan menunjukkan ketidakpuasan terhadap pekerjaan. Sifat kepuasan kerja tidak hanya tergantung pada satu tetapi banyak faktor seperti promosi, paket penggajian, pengawasan, pekerjaan, tim kerja dan kondisi kerja secara umum akan meningkatkan ataupun menyebabkan keterikatan karyawan pada perusahaan (Vokić \& Hernaus, 2015)

\section{Pengaruh Pelatihan Kerja terhadap Keterikatan Karyawan}

Menurut Lai et al., (2015) pelatihan merupakan salah satu kegiatan untuk meningkatkan keterampilan kerja karyawan agar karyawan lebih mengenal organisasi dan keterlibatan untuk mempersiapkan karyawan pada masa yang akan datang, hal ini membuat karyawan merasa dihargai karena upaya mereka diperlukan oleh organisasi sehingga akan menyebabkan keterikatan karyawan pada perusahaan. Karyawan yang 
diberikan pelatihan yang cukup cenderung akan lebih terikat pada pekerjaan dan organisasi, keterikatan karyawan juga menunjukkan sikap, perilaku, dan perhatian yang positif terhadap sesama rekan kerja (Ologbo \& Sofian, 2013).

Menurut Manuel (2014) pelatihan memberikan karyawan keterampilan kerja, kemampuan, dan pengetahuan yang diperlukan dalam sebuah jenis pekerjaan. Efek ini dapat dijelaskan oleh sebuah organisasi tertarik untuk berinvestasi dalam pelatihan untuk karyawan dan memberikan mereka kepercayaan diri dan juga bermaksud untuk mengandalkan mereka dimasa depan, mereka akan memberikan usaha yang lebih dan kerja dengan lebih effektif. Pelatihan dan pengembangan karyawan merupakan elemen kunci yang dapat meningkatkan keterikatan karyawan, jika karyawan mendapatkan pelatihan yang cukup untuk mengatasi tekanan pekerjaan dan rumah hal ini dapat meningkatkan produktifitas kerja dan membuat karyawan lebih terikat pada pekerjaannya. Pelatihan merupakan pengalaman pembelajaran yang dapat membawa perubahan secara permanen dalam sikap dan produktivitas kerja karyawan. Pelatihan yang diberikan biasanya memperhatikan peningkatan keterampilan dan pengetahuan karyawan yang dapat digunakan dalam performa kerja (Azeem et al., 2013).

\section{Model Penelitian dan Perumusan Hipotesis}

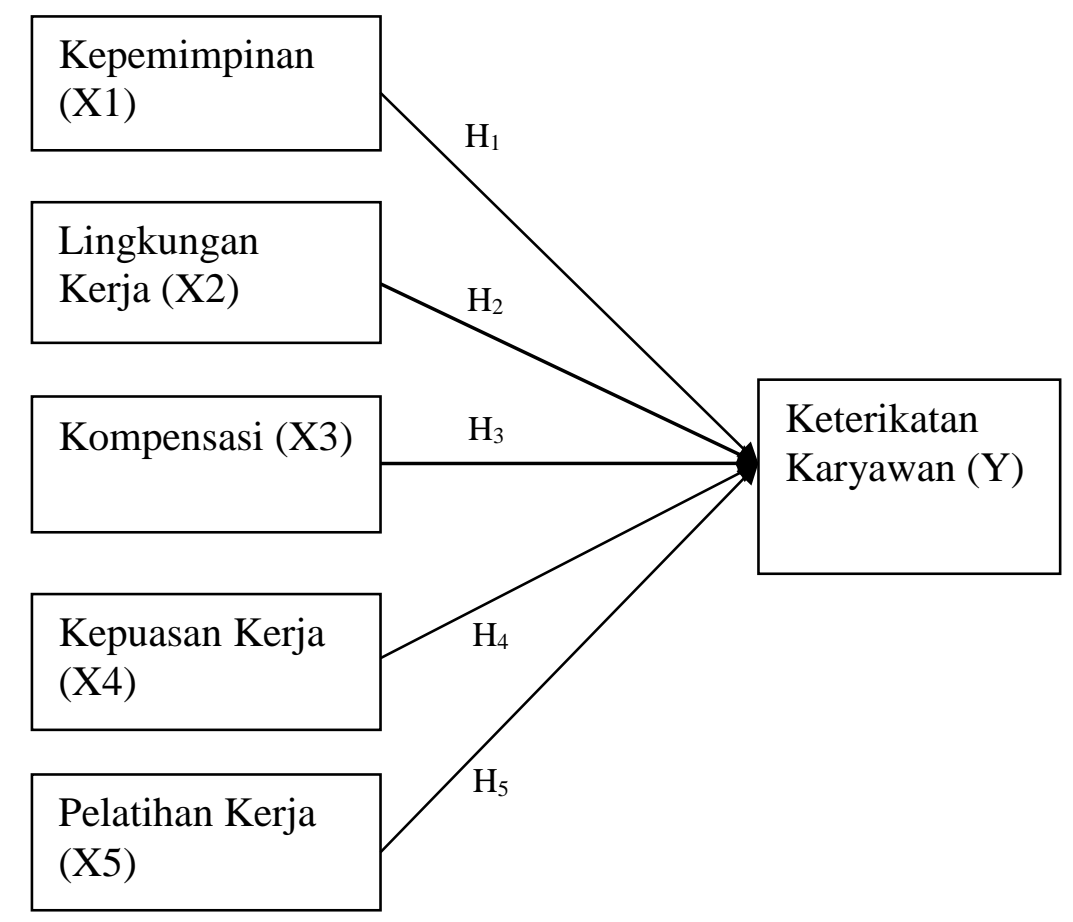

Perumusan hipotesis dari penelitian di atas adalah sebagai berikut :

$\mathrm{H}_{1}$ : $\quad$ Kepemimpinan (X1) berpengaruh signifikan terhadap keterikatan karyawan (Y)

$\mathrm{H}_{2}$ : Lingkungan kerja (X2)berpengaruh signifikan terhadap keterikatan karyawan (Y)

$\mathrm{H}_{3}$ : Kompensasi (X3) berpengaruh signifikan terhadap keterikatan karyawan (Y)

$\mathrm{H}_{4}$ : $\quad$ Kepuasan kerja (X4) berpengaruh signifikan terhadap keterikatan karyawan (Y)

$\mathrm{H}_{5}$ : $\quad$ Pelatihan kerja (X5) berpengaruh signifikan terhadap keterikatan karyawan (Y) 


\section{METODE PENELITIAN}

Bila ditinjau dari segi tujuan penelitian, maka penelitian ini termasuk dalam kategori penelitian dasar yang bertujuan untuk mengembangkan teori, dimana penelitian ini digunakan hanya untuk melakukan penelitian dilingkungan akademik (Indriantoro \& Supomo, 2012). Penelitian ini disusun untuk menjadi suatu karya ilmiah yang bertujuan untuk pengembangan ilmu pengetahuan serta menjadi kualifikasi untuk meraih gelar kesarjanaan. Namun apabila ditinjau dari segi permasalahannya, maka penelitian ini termasuk dalam penelitian kausal komparatif (Causal-Comparative Research) (Indriantoro \& Supomo, 2012).

\section{Objek Penelitian}

Populasi dalam penelitian ini adalah sebanyak 3,520 karyawan dari hotel klasifikasi bintang empat yang berada di Batam. Sampel penelitian diambil dari 350 orang responden yang merupakan karyawan dari lima hotel bintang empat di Batam. Karyawan hotel dipilih sebagai objek penelitian karena sektor industri pariwisata yang terus berkembang di Batam yang ditunjukkan dengan semakin banyaknya kunjungan wisatawan mancanegara dan domestik, maka peran hotel sebagai komponen pengembangan industri pariwisata semakin penting. Agar hotel dapat maju dan berkembang dibutuhkan karyawan yang bekerja maksimal dan memiliki keterikatan dengan hotel tempatnya bekerja.

Berdasarkan tabel Krejcie Morgan, dengan jumlah populasi 3,520 maka sampel penelitian minimum yang diperlukan berjumlah 346 responden. Tetapi untuk mengantisipasi adanya kuesioner yang tidak kembali atau tidak diisi dengan lengkap, aka jumlah kuesioner yang disebarkan adalah sebanyak 350 responden, yaitu karyawan dari lima hotel berbintang empat di Batam.

\section{Metode Pengumpulan Data}

Tahapan pembagian kuesioner dimulai dengan melakukan pengamatan langsung ke lokasi kerja beberapa hotel berbintang di kota Batam. Pengamatan dilakukan agar proses penyebaran kuesioner dapat berlangsung dengan lancar dan tepat pada objek penelitian. Selanjutnya dilakukan penyebaran kuesioner pada karyawan secara merata pada beberapa posisi dan bidang kerja untuk mengurangi bias. Pembagian kuesioner dilakukan pada saat jam istirahat agar tidak mengganggu waktu kerja karyawan. Selanjutnya dikumpulkan kembali pada hari yang sudah ditentukan untuk meminimalisir hilangnya kuesioner.

Penelitian ini menggunakan data primer dan sekunder. Data primer yang diperoleh oleh penulis adalah dari objek penelitian secara langsung, dari kuesioner yang dibagikan sedangkan data sekunder adalah data yang diperoleh lewat pihak lain, seperti dari internet, data organisasi, jurnal dan buletin. Data sekunder biasanya berwujud data dokumentasi atau data laporan yang telah tersedia (Indriantoro dan Supomo, 2012).

\section{HASIL PENELITIAN}




\section{Hasil Uji Kuantitatif \\ Hasil Uji Outlier}

Berdasarkan hasil pengujian terhadap 350 responden, tidak terdapat nilai z-score yang lebih besar dari $+3,0$ atau lebih kecil $-3,0$. Sehingga untuk analisis berikutnya semua responden diikutsertakan karena dianggap wajar dalam memberikan respon terhadap kuesioner yang disebarkan, dan responden tetap berjumlah 350 orang. Nilai yang kurang atau lebih dari ambang batas $z$-score akan dianggap menyimpang dari rata-rata dan data tersebut akan divalidasi untuk tidak dianalisa lebih lanjut (Ghozali, 2011).

\section{Uji Kualitas Data}

\section{Hasil Uji Validitas}

Hasil uji validitas yang dilakukan terhadap 30 pertanyaan dalam kuesioner ditemukan ada 2 pertanyaan yang tidak valid, yaitu pada pertanyaan lingkungan kerja 5 dan kepuasan kerja 4, sehingga pertanyaan yang tidak valid tidak diikut sertakan dalam proses pengolahan data selanjutnya. Uji ini akan dinyatakan valid jika suatu konstruk mempunyai nilai factor loading diatas 0,6 (Ghozali, 2011).

\section{Hasil Uji Reliabilitas}

Setelah melakukan uji reliabilitas, diperoleh nilai Cronbach alpha dari semua variabel menunjukkan bahwa semua variabel melebihi nilai batas konsistensi 0,6 (Ghozali, 2011) sehingga semua variabel yang digunakan dalam penelitian ini dinyatakan reliabel.

\section{Uji Asumsi Klasik}

\section{Hasil Uji Normalitas}

Melalui uji normalitas dapat dilihat bahwa P_Plot menunjukkan data memiliki distribusi yang normal dan menyebar mengikuti garis diagonal, disimpulkan bahwa semua model regresi yang dipergunakan dalam penelitian ini layak dipakai karena memenuhi asumsi normalitas.

\section{Hasil Uji Multikolinearitas}

Hasil uji multikolinearitas terhadap variabel bebas tidak ditemukan nilai yang menunjukkan nilai tolerance di bawah 0,10, yang artinya tidak ada korelasi antar variabel bebas. Hasil pengujian yang disajikan pada Tabel 4.9 menunjukkan nilai VIF kurang dari 10 dan nilai tolerance lebih dari 0,1. Jadi, dapat disimpulkan bahwa tidak terdapat multikolinearitas antar variabel bebas dalam regresi (Ghozali, 2001).

\section{Hasil Uji Heterokedastisitas}

Hasil uji heterokedastisitas dengan uji glejser terhadap variabel kepemimpinan, lingkungan kerja, motivasi, kompensasi dan kepuasan kerja terhadap komitmen organisasi. Variabel independen dan dependen terdistribusi normal dengan nilai diatas 0,05 maka dapat disimpulkan tidak terjadi heterokedastisitas.

\section{Uji Hipotesis Hasil Uji F}


Uji $\mathrm{F}$ digunakan untuk menunjukkan apakah semua variabel independen mempunyai pengaruh secara bersama sama terhadap variabel dependen. Uji F dilakukan dengan melihat nilai signifikansi. Nilai probabilitas yang kurang dari 0,05 maka model regresi dapat digunakan untuk memprediksi variabel dependen (Ghozali, 2001). Hasil uji F diperoleh tingkat probabilitas sebesar 0,000 . Tingkat probabilitas 0,000 lebih kecil dari 0,05 sehingga model regresi tersebut dapat digunakan untuk memprediksi atau mengukur variabel komitmen organisasi sebagai variabel dependen.

\section{Hasil Uji t}

Berdasarkan hasil uji t diketahui bahwa nilai signifikansi dari $\mathrm{H}_{1}$ sebesar 0,089 dan nilai beta sebesar 0,091 sehingga dapat disimpulkan bahwa tidak terdapat pengaruh signifikan antara variabel kepemimpinan terhadap keterikatan karyawan. Temuan ini menunjukkan bahwa gaya kepemimpinan dalam sebuah hotel tidak berdampak signifikan terhadap keterikatan karyawan pada hotel tempatnya bekerja. Hasil penelitian ini tidak sesuai dengan penelitian sebelumnya dari Khuong dan Yen (2014), Sundaray (2014), dan Bedarkar dan Pandita (2014).

Berdasarkan hasil uji t diketahui bahwa nilai signifikansi dari $\mathrm{H}_{2}$ sebesar 0,001 dan nilai beta sebesar 0,217 sehingga dapat disimpulkan bahwa terdapat pengaruh signifikan antara lingkungan kerja terhadap keterikatan karyawan. Temuan ini menunjukkan bahwa lingkungan kerja di hotel tempatnya bekerja berdampak signifikan terhadap peningkatan keterikatan karyawan pada hotel tersebut. Hasil penelitian ini sesuai dengan penelitian sebelumnya dari Anita (2014) dan Naidoo dan Martins (2014).

Berdasarkan hasil uji t diketahui bahwa nilai signifikansi dari $\mathrm{H}_{3}$ sebesar 0,011 dan nilai beta sebesar 0,199 sehingga dapat disimpulkan bahwa tingkat kompensasi dan penerapan aturan yang berkaitan dengan kebijakan kompensasi dalam sebuah organisasi berdampak signifikan terhadap keterikatan karyawan. Hasil penelitian ini sesuai dengan penelitian sebelumnya dari Alvi et al., (2014), Sundaray (2014), Swathi (2013) dan Ravikumar (2013).

Berdasarkan hasil uji t diketahui bahwa nilai signifikansi dari $\mathrm{H}_{4}$ sebesar 0,020 dan nilai beta 0,150 sehingga disimpulkan bahwa dalam penelitian ini bahwa kepuasan kerja berpengaruh signifikan terhadap keterikatan karyawan. Hasil penelitian ini menunjukkan bahwa kepuasan kerja yang didapatkan karyawan dalam pekerjaannya akan membantu meningkatkan keterikatan karyawan pada hotel tersebut. Hasil penelitian ini sesuai dengan penelitian sebelumnya dari Vokić dan Hernaus (2015), Sundaray (2014) dan Swathi (2013).

Berdasarkan hasil uji t diketahui bahwa nilai signifikansi dari $\mathrm{H}_{5}$ sebesar 0,000 dan nilai beta 0,368 sehingga dapat disimpulkan bahwa dalam penelitian ini bahwa pelatihan kerja berpengaruh signifikan terhadap keterikatan karyawan. Hasil penelitian ini menunjukkan bahwa pelatihan kerja yang sesuai dengan kebutuhan pekerjaan karyawan akan meningkatkan keterampilan kerjanya dan membantu meningkatkan keterikatan karyawan pada pekerjaannya di hotel tersebut. Hasil penelitian ini sesuai dengan penelitian sebelumnya dari Lai et al., (2015), Azeem et al., (2015), Manuel (2014) dan Anita (2014).

\section{Hasil Koefisien Determinasi $\left(\mathbf{R}^{2}\right)$}


Pada pengujian koefisien determinasi $\left(\mathrm{R}^{2}\right)$ ini dilihat seberapa besar variabel independen dalam memberikan informasi terhadap variabel dependen. Tabel 4.10 menunjukkan angka adjusted $\mathrm{R}^{2}$ sebesar 0,548 yang artinya bahwa kemampuan dari variabel independen dalam menjelaskan variabel dependen sebesar 54,8\% sedangkan sisanya yaitu 45,2\% dijelaskan oleh variabel lain yang tidak diteliti dalam penelitian ini seperti budaya kerja dan kerjasama tim (Ravikumar, 2013).

\section{KESIMPULAN}

Hasil penelitian menunjukkan bahwa semua variabel yang diteliti dalam penelitian ini yaitu kepemimpinan, lingkungan kerja, kompensasi, kepuasan kerja dan pelatihan kerja berpengaruh signifikan terhadap keterikatan karyawan hotel berbintang 4 di kota Batam yang menjadi objek dalam penelitian ini.

Kepemimpinan tidak mempunyai pengaruh yang signifikan positif terhadap tingkat keterikatan kerja karyawan hotel berbintang. Pemimpin belum menjadi faktor dalam meningkatkan keterikatan karyawan pada hotel tempatnya bekerja tersebut.

Lingkungan kerja juga memberikan kontribusi yang signifikan dalam meningkatkan tingkat keterikatan kerja karyawan. Tata letak dan desain ruangan yang baik akan meningkatkan keterikatan karyawan, seperti ruangan kerja yang bersih dan nyaman, penerangan ruangan yang cukup, penataan perlengkapan kerja yang sesuai akan semakin meningkatkan rasa keterikatan karyawan terhadap pekerjaaannya sehingga lingkungan kerja yang kondusif, bersih dan teratur akan membantu meningkatkan keterikatan karyawan terhadap hotel tempatnya bekerja.

Kepuasan kerja merupakan faktor yang berpengaruh signifikan positif terhadap keterikatan karyawan pada hotel tempatnya bekerja. Untuk dapat meningkatkan rasa keterikatan kerja karyawan maka karyawan membutuhkan dukungan sarana, peralatan dan perlengkapan kerja yang lengkap dan memadai dalam melakukan pekerjaan sehingga semua pekerjaan dapat berjalan dengan lancar sehingga akan dapat meningkatkan kepuasan kerja karyawan.

Kompensasi mempunyai hubungan yang erat terhadap tingkat keterikatan karyawan, dimana kepuasan karyawan akan sistem pemberian kompensasi yang baik akan turut memberikan motivasi pada karyawan untuk bekerja dengan lebih baik lagi. Kebijakan kompensasi dapat dilakukan dengan cara memberikan insentif atau tunjangan yang berkaitan dengan pencapaian target kerja. Sehingga karyawan yang berprestasi dan mampu memenuhi target kerja yang ditentukan akan terus termotivasi untuk bekerja lebih baik lagi dan akan meningkatkan rasa keterikatan karyawan terhadap hotel tempatnya bekerja.

Pelatihan kerja yang diberikan pada karyawan mempunyai peranan penting dalam meningkatkan keterikatan karyawan terhadap hotel tempatnya bekerja. Karyawan yang diberikan pelatihan dengan baik akan berusaha untuk meningkatkan prestasi kerja dan berusaha memberikan hasil kerja terbaik karena karyawan akan merasa merupakan bagian dari perusahaan. Sehingga dengan tumbuhnya rasa memiliki terhadap organisasi akan berdampak signifikan terhadap peningkatan keterikatan kerja karyawan tersebut.

\section{UCAPAN TERIMA KASIH}


Penulis mengucapkan terimakasih kepada Kepala Program Sarjana Manajemen Fakultas Ekonomi Universitas Internasional Batam dan juga teman teman peneliti yang telah mendukung dan memberikan semangat pada peneliti untuk melakukan penelitian ini.

\section{DAFTAR PUSTAKA}

Ali, S dan Farooqi, Y.A (2014) Effect of Work Overload on Job Satisfaction, Effect of Job Satisfaction on Employee Performance and Employee Engagement (A Case of Public Sector University of Gujranwala Division). International Journal of Multidiciplinary Sciences and Engineering Vol. 5 No. 8

Alvi, K.H., Khan, M.A., Ahmed, A.A., dan Zulfiqar, M (2014) A Study of Employee Compensation and Employee Job Engagement on Banks of Lahore, Pakistan. Science International Journal (Lahore), 26 (5), 2411-2414 (2014)

Anitha J. (2014) Determinants of Employee Engagement and Their Impact on Employee Performance. International Journal of Productivity and Performance Management Vol. 63 No. 3, 2014

Azeem, M.F., Rubina dan Paracha, A.T (2013) Connecting Training and Development with Employee Engagement: How does it Matter? World Applied Sciences Journal 28 (5): 696-703, 2013

Bedarkar, M dan Pandita, D (2014) A Study on the Drivers of Employee Engagement Impacting Employee Performance. Social and Behavioral Sciences 133 (2014) $106-115$

Ghozali, I (2011). Aplikasi Analisis Multivariate dengan Program SPSS, Badan Penerbit Universitas Diponegoro, Semarang

Hair, J.F., Black, W.C., Babin, B.J., dan Anderson, R.E. (2010). Multivariate Data Analysis. Seventh Edition. Prentice Hall, Upper Saddle River, New Jersey.

Indriantoro, N \& Supomo, B (2012). Metedologi Penelitian Bisnis. Yogyakarta : Edisi Pertama, Penerbit BPFE.

Jian Ming Luo, J.M., Tan, S dan Lam, C.F (2015) An Analysis of the Factors Affecting the New Generation Employee Engagement in the Manufacturing Industry in China. International Journal of Business and Management; Vol. 10, No. 10; 2015

Khuong, M.N. dan Yen, N.H (2014) The Effects of Leadership Styles and Sociability Trait Emotional Intelligence on Employee Engagement - A Study in Binh Duong City, Vietnam. International Journal of Current Research and Academic Review Vol. 2 NO. 1 (January, 2014) pp. 121-136

Lai, P.Y., Lee, J.S., Lim, Y.X., Yeoh, R.G., dan Mohsin, F.H (2015) The Linkage between Training and Development and Co-Worker Support towards Employee Engagement in Hotel Industry. International Journal of Scientific and Research Publications, Volume 5, Issue 5, May 2015

Manuel, F.D (2014) The Effect of Training and Development on Employee Engagement. World Review of Business Research Vol. 2. No. 5.

Naidoo, P dan Martins, N (2014) Investigating the Relationship between Organizational Culture and Work Engagement. Problems and Perspectives in Management, Volume 12, Issue 4, 2014 
Ologbo, A.C dan Sofian, S (2013) Individual and Organizational Factors of Employee Engagement on Employee Work Outcomes. International Journal of Business and Behavioral Sciences Vol. 3, No.3; March 2013

Ravikumar, T (2013) Study on Impact of Teamwork, Work Culture, Leadership and Compensation on Engagement Level of Employees in MSMES in India. International Journal of Advanced Research in Management and Social Sciences Vol. 2 No. 8 August 2013

Suharti, L dan Suliyanto, D (2012) The Effects of Organizational Culture and Leadership Style toward Employee Engagement and Their Impacts toward Employee Loyalty. World Review of Business Research Vol. 2. No. 5. September 2012. Pp. $128-139$

Sundaray, B.K (2011) Employee Engagement: A Driver of Organizational Effectiveness. European Journal of Business and Management Vol 3, No.8, 2011

Swathi, S (2013) Effecting Employee Engagement Factors. International Journal of Scientific and Research Publications, Volume 3, Issue 8, August 2013

Vokić, N.P dan Hernaus, T (2015) The Triad of Job Satisfaction, Work Engagement and Employee Loyalty - The Interplay among the Concepts. Social and Behavioral Sciences 133 (2015) $106-115$ 